\title{
PILAR PENDIDIKAN DALAM PERSPEKTIF IMAM AL-SYATHBY
}

\author{
Al Ikhlas*, Ahmad Rivauzi, Wirdati \\ Universitas Negeri Padang \\ *E-mail: alikblas@fis.unp.ac.id
}

\begin{abstract}
This study aims to reveal about the pillars of education in the perspective of Imam al-Syathiby. This research is library research where the authors explore the opinion of Imam al-Syathiby in the book al-Muwafaqat fi Ushul al-Syari'ah that related with education. After the data is collected, it is processed by qualitative approach method. The instrument in this study is the author bimself. From this study it can be concluded that the concept of education according to Imam al-Syathiby has four pillars; first, materials (science), second, teacher, third, method and forth, student. Every pillar in education must be paid attention proportionally. If not, education will not work properly. The further impact is that the goodness of human life both in the world and in the hereafter will not be realized. In this world human will be miserable, in the hereafter they will be misfortune.
\end{abstract}

Keywords: Pillars of Education, Islamic Education, Imam al-Syathiby

\begin{abstract}
ABSTRAK
Penelitian ini bertujuan untuk mengungkap tentang pilar pendidikan dalam perspektif Imam alSyatbiby. Penelitan ini berbentuk library research dimana penulis mengeksplorasi pendapat Imam al-Syathiby dalam kitab al-Muwafaqat fi Ushuli al-Syari ah yang berkaitan dengan pendidikan.Setelah data terkumpul, diolah dengan metode pendekatan kualitatif. Adapun instrument dalam penelitian ini adalah penulis sendiri. Dari penelitian ini dapat disimpulkan babwa konsep pendidikan menurut Imam al-Syathiby memiliki empat pilar, yaitu, materi (ilmu), guru, metode dan murid. Setiap pilar dalam pendidikan tersebut harus mendapatkan perbatian sesuai dengan porsinya. Jika tidak, maka pendidikan tidak akan berjalan dengan baik. Dampak lebih jaubnya adalah tidak akan tervinudnya kemashlahatan pada kebidupan manusia di dunia dan akbirat. Di dunia manusia akan sengsara di akbirat nanti manusia akan celaka.
\end{abstract}

Kata Kunci: Pilar Pendidikan, Pendidikan Islam, Imam al-Syathiby

TARBAWY: Indonesian Journal of Islamic Education - Vol. 5, No.1 (2018) $\mid 1$ 


\section{PENDAHULUAN}

Pendidikan selalu akan menjadi kebutuhan bagi manusia selama ia masih hidup. Sebab manusia perlu untuk mempelajari berbagai hal dalam kehidupan sehingga manusia mampu bertahan dan mencipta peradaban. Tanpa pendidikan maka manusia tidak ada artinya dan peran sebagai khalifah tidak akan terlaksana dengan semestinya.

Berdarkan kepada Undangundang No. 20 Tahun 2003 pendidikan adalah usaha sadar dan terencana untuk mewujudkan suasana belajar dan proses pembelajaran agar peserta didik secara aktif mengembangkan potensi dirinya untuk memiliki kekuatan spritual keagamaan, pengendalian diri, kepribadian, kecerdasan, akhlak mulia, serta keterampilan yang diperlukan dirinya, masyarakat, bangsa, dan negara.

Adapun tujuan dari pendidikan yang juga tertuang dalam Undangundang No. 20 Tahun 2003 itu adalah mengembangkan potensi peserta didik agar menjadi manusia yang beriman dan bertakwa kepada Tuhan Yang Maha Esa, berakhlak mulia, sehat, berilmu, cakap, kreatif, mandiri, dan menjadi warga negara yang demokratis serta bertanggungjawab.

Agar sampai pada tujuan yang diinginkan maka dibutuhkanlah sebuah sistem. Menurut Sanafiah Faisal sistem adalah menuju kepada totalitas dan bertujuan dan tersusun dari rangkaian unsur dan komponen. (Feisal, 1981, hal. 25).

Dalam hal ini, pendidikan dapat dikatakan sebuah sistem karena ia memiliki elemen yang saling berkaitan antara satu dengan lainnya. Kaitan tersebut terorganisir atau pun tersusun dengan baik untuk mewujudkan sebuah tujuan yang diiginkan.

Imam al-Syathiby merupakan tokoh besar dalam pendidikan Islam pada abad ke VIII H. Meskipun beliau lebih dikenal sebagai ulama yang pakar dalam bidang Maqashid al-Syaria ab alIslamiyah dan bahkan digelari sebagai Bapak Maqashid al-Syaria ab al-Islamiyah al-Ula (Ubaidy, 1996, hal. 11), tapi sumbangsih beliau dalam dunia penididkan sangat luar biasa.

Dalam maha karya beliau yang berjudul al-Munvafaqat fi Ushuli alSyari ah yang notabenenya adalah kitab Ushul Fikih, Imam al-Syathiby mengurai pilar-pilar penting dalam pendidikan dengan rinci dan sistematis. Sehingga, dengan memahami pilarpilar tersebut, barulah bisa dipahami pendidikan sebagai sebuah sistem yang terintegrasi dalam mewujudkan kemashlahatan.

Dalam penelitian ini, penulis mengupas tentang pilar-pilar pendidikan yang dipaparkan oleh Imam al-Syathiby. Semoga mampu menambah khazanah ilmiah tentang pendidikan Islam di Indonesia.

\section{METODE PENELITIAN}

Penelitian ini adalah library research dengan pendekatan yang dilakukan adalah pendekatan kualitatif karena dalam penelitian ini, peneliti berupaya untuk meng-explore pemikiran Imam al-Syathiby dalam memandang sebuah permasalahan khususnya dalam bidang pendidikan.

Dengan metode ini diharapkan dapat memberikan sebuah gambaran 
yang komprehensif tentang pemikiran Imam al-Syathiby dalam bidang pendidikan.

Adapun yang dimaksud dengan penelitian kualitatif adalah penelitian yang menghasilkan penemuan penemuan yang tidak dapat dicapai dengan menggunakan prosedurprosedur statistik atau cara-cara lain dari kuantifikasi. (Creswell, 1998, hal. 24).

Penelitian kualitatif adalah salah satu prosedur penelitian yang menghasilkan data deskriptif berupa ucapan atau tulisan dan perilaku orang-orang yang diamati. Pendekatan kualitatif diharapkan mampu menghasilkan uraian yang mendalam tentang ucapan, tulisan, dan atau perilaku yang dapat diamati dari suatu individu, kelompok, masyarakat, dan atau organisasi tertentu dalam suatu setting konteks tertentu yang dikaji dari sudut pandang yang utuh, komperhensif, dan holistik.

Sedangkan instrumen dari penelitian ini adalah peneliti sendiri yang mengumpulkan literatur yang menyinggung tentang pendidikan dalam kitab al-Muwafaqat fi Ushuli alSyariab.

\section{HASIL DAN PEMBAHASAN}

Imam al-Syathiby menetapkan bahwa ada empat pilar atau unsur utama dalam pendidikan. Keempat pilar tersebut saling mengokohkan antara satu dengan lainnya. Jika salah satu unsur tidak terwujud, maka tidak tercapailah tujuan pendidikan seperti yang diinginkan. Oleh sebab itu, keempat pilar pendidikan tersebut mesti mendapatkan perhatian sesuai dengan porsinya. Sehingga bisa saling bersinergi dalam mewujudkan tujuan pendidikan berupa kemashalahatan baik dunia dan akhirat nantinya.

Pilar pertama, ilmu (materi pendidikan). Imam al-Syathiby membagi ilmu kepada tiga bagian:

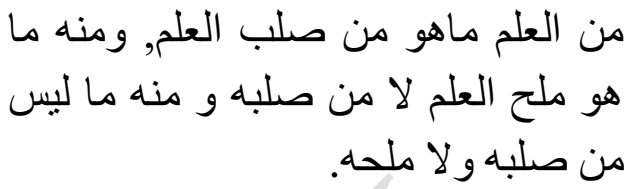

"Ilmu ada yang dikategorikan dengan shulb al-ilmi, mulahu al-ilmi dan ma laisa min shulbihi wa la min mulahih." (alSyathiby, 2006, vol. I, hal. 51)

Pada teks di atas yang merupakan pengantar kesembilan dalam kitab al-Muwafaqat, Imam alSyathiby membagi ilmu kepada tiga kategori. Pertama shulb al-ilmi (saripati ilmu), kedua, mulahu al-ilmi (bumbu ilmu) dan ketiga, kategori yang tidak dikelompokkan pada shulbu al-ilmi dan mulabu al-ilmi.

Kategori pertama, shulb al-ilmi. Imam al-Syathiby menyebutkan bahwa yang dimaksud dengan shulb al-ilmi adalah al-syariab atau agama Islam. Dalam pandangan Imam al-Syathiby bahwa al-Syari ah merupakan materi utama dalam pendidkan. Sebab agama Islam merupakan al-ashl (pondasi) dan al-mu 'tamad (yang mesti diterima). Disamping itu, agama Islam bersifat absolut (pasti kebenarannya) karena ia lahir dari sumber yang absolut (wahyu). Agama Islam terpelihara baik ubsul maupun furu'-nya seiring dengan penjagaan Allah Swt terhadap alQur'an yang merupakan sumber utamanya. (al-Syathiby, 2006, vol. I, hal. 51). 
Imam al-Syathiby menegaskan bahwa hanya agama Islam yang mampu menciptakan kemashlahatan bagi manusia pada kehidupan dunia dan akhirat. Kemashalahatan yang dimaksud tersebar dalam dalam tinggkatan yang berbeda sesuai dengan kebutuhan dan kemampuan untuk mewujudkannya. Tingkatan yang paling utama adalah dharuriyat (tingkatan primer) kemudian bajiyat (tingkatan sekunder) dan yang terakhir adalah tahsniyat (tingkatan tersier). Dan pada setiap tingkatan tersebut juga terdapat mukmil (penyempurna) yang merupakan bagian yang tidak terpisahkan dengan tingkatan masingmasing. Oleh sebab itu, al-Syari ab ataupun agama Islam menjadi materi inti dan penting dalam sebuah sitem pendidikan.

Imam al-Syathiby menjadikan agama Islam sebagai shulb al-ilmi karena hanya agama Islam yang bisa menuntun manusia untuk menghasilkan amalan berkualitas. Sebab, ilmu yang tidak menghasilkan amalan maka tidak akan memberikan manfaat manusia. Meskipun manusia dimuliakan dengan ilmunya, tetapi manusia tidak akan dibalasi dengan ilmu yang ia miliki. Manusia hanya akan dibalasi berupa kebaikan ataupun keburukan dikarenakan amalannya.(alSyathiby, 2006, vol. I, hal. 32)

Atas pertimbangan ini, Imam alSyatiby menempatkan ilmu agama Islam sebagai inti utama yang harus dipelajari karena dalam Islam telah digariskan amalan yang mesti dikerjakan dan amalan yang mesti dihindari agar manusia memperoleh kemashlahatan yang berbentuk kebahagiaan hidup, baik di dunia dan akhirat nantinya.

Menempatkan agama Islam sebagai materi inti ataupun saripati ilmu dalam pendidikan dikuatkan dengan tiga karakteristik yang dimilikinya, yaitu: Pertama, Islam bersifat umum dan universal. Artinya Islam sebagai materi dalam pendidikan memiliki hukum yang bersifat umum dan universal sehingga mampu menyesuaikan dengan beragam tindak tanduk manusia tanpa ada pengecualian. Pada hukum yang tampak seperti khusus, jika dikaji lebih dalam akan memberikan pemahaman bahwa muara hukum tersebut kembali kepada keumuman nilai dalam ajaran Islam. Pengkhususuan hukum pada kewajiban denda bagi aqilah pada pembubuhan kembali kepada konsep hajiyat yang bersifat umum.

Kedua, besifat tetap dan tidak akan lenyap. Setelah dinyatakan sebagai ajaran yang sempurna pada haji Wada', maka tidak ada lagi pengurangan dan penambahan pada ajaran Islam. Hal ini menunjukkan bahwa Islam sebagai materi dalam pendidikan merupakan meteri yang sempurna. Sebab tidak akan ada perubahan-perubahan yang prinsip dalam ajarannya sehingga meski Islam diajarkan hingga keakhir zaman maka tidak akan ada perubahan dari segi nilai dan hukum yang dikandungnya.

Ketiga, Islam sebagai materi ilmu dalam pendidikan karena Islam sebagai rujukan dalam memutuskan perkara atau rujukan dalam mencarikan solusi dalam berbagai permasalahan. Bukan sebaliknya, dimana Islam dijadikan sebagai hanya dijadikan sebagai objek. 
Islam sebagai manteri ilmu berfungsi sebagai hakim atau penentu yang membedakan kualitas amalan. Sebab, tidak ada gunanya ilmu kalau tidak menuntun manusia untuk beramal. Dan meskipun manusia mendapatkan tempat kemulian dengan ilmunya, tapi mereka tidak akan dibalasi dengan ilmu tersebut. Melainkan dengan amalan yang mereka lakukan. (alSyathiby, 2006, vol I, hal. 52-53)

Kategori kedua, mulahu al-ilmi. Yaitu ilmu yang tidak termasuk ke dalam kategori shulb al-ilmi. Agaknya yang dimaksud dengan mulah al-ilmi adalah ilmu-ilmu pendukung atau pelengkap dari inti ilmu. Sebab ilmu ini tidak bersifat absolut (pasti kebenarannya) dan juga tidak lahir dari sumber yang absolut (wahyu). Akan tetapi ilmu ini datang sari sumber yang zhanny (hasil interpretasi pemikiran manusia). (al-Syathby, 2006, vol I, hal. 53).

Imam al-Syathiby menjelaskan menggambarkan ilmu dalam bentuk ini dengan sebuah kesenangan dan kepuasan bagi diri manusia. Kesenangan tersebut dapat memuaskan fantasi keilmiahan dalam bentuk metafor. Ilmu ini diperlukan jika manusia sampai pada titik kepenatan jiwa dan akal. Ilmu dalam bentuk ini tidak sama dengan bentuk yang pertama baik dari segi nilai ataupun manfaatnya. Akan tetapi kedudukan ilmu dalam bentuk kedua ini juga tidak bisa dipisahkan dari bentuk ilmu yang pertama sebab dalam beberapa ketentuan, ilmu dalam bentuk ini akan menguatkan ilmu dalam bentuk pertama. Oleh sebab itu Imam al-Syathiby menamakannya dengan mulah atau mungkin seperti bumbu pada makanan.

Dari segi sumber, ilmu dalam kategori shulb lahir dari sumber yang qathi (wahyu) sehingga tidak diragukan lagi ke kekuatannya. Sedangkan ilmu dalam kategori mulab merupakan hasil interpretasi dan formulasi akal manusia. Sehingga ilmu dalam kategori mulab tidak memiliki kekuatan yang qath $i$ atau absolut. Akan tetapi hanya bersifat zhanny atau sesuatu yang terbuka peluangnya untuk diperdebatkan. Sebab fomulasinya tergantung kepada kemampuan berfikir oleh orang yang melakukannya. Dan besar kemungkinan terjadinya perbedaan hasil pemikiran antara satu dengan lainnya karena dipengaruhi berbagai faktor.

Untuk lebih mendekatkan pemahaman pada bentuk ilmu yang kedua ini, Imam al-Syathiby memberikan beberapa contoh yaitu, hikmah yang dirumuskan dibalik ibadah. Kenapa dalam berwudu hanya membasuh anggota tubuh tertentu saja? Kenapa shalat hanya dalam bentuk teretentu dengan mengangkat kedua tangan, berdiri tegak, rukuk, sujud dan tidak boleh melakukan gerakan di luar dari ketentuan tersebut (al-Syathiby, 2006, vol. I, hal. 53).

Menggali hikmah di balik ritual tersebut akan memberikan kepuasan fikiran dan batin bagi setiap orang yang mengkajinya, akan tetapi hasil pengkajian mereka bukanlah sesuatu yang absolut. Melainkan hanya sebuah interpretasi akal manusia yang mungkin berbeda pemahamannya antara satu dengan yang lain. 
Atau, periwayatan hadis dari generasi ke generasi dengan cara tertentu pada hadis musalsal yang hal demikian tidak mesti demikian karena tidak akan mempengaruhi substansi hadis. Sebab menggunakan cara tertentu dalam periwayatan tidak akan menambah atau mengurangi nilai hadis yang disampaikan. Namun yang demikian menjadi penting dilakukan karena mampu memberikan kepuasan bagi pada setiap tingkatan dalam menerima hadis meskipun yang demikian tidak bisa dijadikan sandaran dalam amal. (al-Syathiby, 2006, vol I, hal. 53).

Pembagian ketiga, ilmu yang tidak dikategorikan sebagai shulb al-ilmi dan tidak juga mulab al-ilmi. Atau ilmu yang tidak bersifat ashalah dan juga tidak bersifat imta'. Sebenarnya, Imam al-Syathiby enggan menye-butnya ilmu sebab ia tidak akan mampu mewujudkan tujuan dari pendidikan. Akan tetapi, ada sebagian orang yang tetap mempelajarinya, meskipun tidak mendatangkan manfaat.

Jika dikomparasikan dengan shub al-ilmi maka akan ada perbedaan yang jauh antara kedua materi ini, sebab pada shub al-ilmi bersifat absolut dan sedangkan bentuk ketiga ini bersifat nisbi (relatif). Pada shulb al-ilmi mesti bersifat umum dan universal sedangkan ia hanya pada bersifat khusus dan lokal. Pada shulb al-ilmi mesti bersifat tetap tidak hilang sedangkan ia bisa hilang dan pada shulb al-ilmi mesti menjadi hakim (rujukan dalam penyelesaian masalah) sedangkan ia tidak bisa dijadikan hakim. (al-Syathiby, 2006, vol. I, hal. 57).
Jika materi yang ketiga ini dikomperasikan dengan mulah al-ilmi juga terdapat perbedaan. Pada mulah alilmi masih dapat diterima oleh akal manusia dan dapat dijadikan sebagai hiburan dalam kepenatan akal dan fikiran meskipun terkadang diperselisihkan. Sedangkan dalam bentuk ini, tidak bisa diterima oleh logika manusia dan juga tidak dapat memberikan semacam penenang pada kepenatan akal dan fikiran. Dan bahkan ilmu dalam bentuk ini bertentangan dengan akal manusia dan sehingga menimbulkan keresahan dalam fikiran dan batin. (al-Syathiby, 2006, vol. I, hal. 57).

Contoh ilmu dalam bentuk ini menurut Imam al-Syathuby adalah ilmu yang diformulasikan oleh kelompok Bathiniyah. Mereka menggunakan ayat-ayat dari al-Quran dan kemudian menginterpretasikannya dengan cara mereka sendiri. Yaitu cara yang tidak benar dan juga tidak dibenarkan berdasarkan akal dan logika. Namun penafsiran dengan cara tersebut menjadi diterima karena bersumber dari seorang imam yang mereka anggap ma'shum atau suci.

Di antara bentuk penafsiran itu adalah dengan mengkaji huruf-huruf al-Qur'an dan menafsirkannya dan mengkorelasikannya dengan ilmu nujum (astrologi). Dan ilmu itu terus berkembang karena sebagian pihak yang tidak mengerti seolah ilmu tesebut bagian dari syariat, karena menggunakan teks-teks agama. (alSyathiby, 2006, vol. I, hal. 58).

Jadi jelas, ilmu yang dijadikan materi dalam pendidikan menurut Imam al-Syathiby adalah ilmu yang

TARBAWY: Indonesian Journal of Islamic Education - Vol. 5, No.1 (2018) |6 
mendorong seseorang untuk beramal, yaitu ilmu tentang syari'ah. Sebab hanya syariah yang mampu mendorong manusia untuk menciptakan amalan sehingga terwujudlah kemashalahatan bagi manusia dunia dan akhirat.

Sedangkan pada bentuk mulahu al-ilmi menjadi penting jika ilmu tersebut dapat melengkapi keberagamaan seseorang dan memberikan kepuasan batin serta hiburan ketika mengalami kebuntuan dalam berfikir dan kepenatan dalam berargumen. Sedangkan bentuk ketiga adalah ilmu yang terlarang karena sumbernya tidak absolut dan interpretasi ilmu tersebut menyesatkan dan sering bertentangan dengan logika manusia.

Pilar kedua dalam pendidikan adalah guru, sebab guru memiliki peran yang sangat penting untuk memindahkan pengetahuan yang ia miliki kepada murid. Imam alSyathibymenjelaskan,
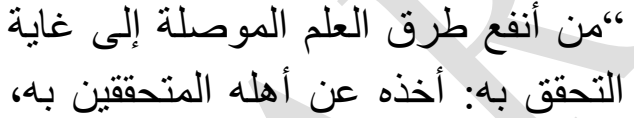

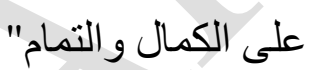

"Di antara cara yang paling efektif untuk. sampai pada tujuan pendidikan adalab dengan mengambil ilmu dari pakar yang mumpuni dengan keilmuannya secara sempurna dan paripurna." (al-Syathiby, 2006, vol. I, hal. 61).

Menjadi guru merupakan profesi yang mulia karena nabi dan rasul adalah seorang guru bagi kaum atu ummatnya. Dan sebaik-baik guru dalam sepanjang peradaban manusia dalah Nabi Muhammad Saw. Jalal, 1977, hal. 19) Allah jelaskan dalam alQur'an:

\author{
وَيُعَلِّمُهُهُ الْكِتَابَ وَالْحِكْمَةَ \\ "(Rasul) mengajari mereka al-kitab \\ (wabyu)dan juga bikmah" (al-Baqarah: \\ 129)
}

Dari teks di atas dapat dipahami bahwa Imam al-Syathby memerintahkan untuk mempelajari sebuah ilmu, maka pelajarilah dari seseorang yang memiliki kepakaran dalam ilmunya. Sebab cara yang demikian akan mewujudkan apa yang menjadi tujuan dalam pendidikan. Dan menimba ilmu dari sosok tersebut mesti secara sempurna dan paripurna, tidak setengah-setengah. Tujuannya adalah untuk melahirkan konsep pemahaman yang baik dan komprehensif.

Dapat dipahami bahwa guru dalam pandangan Imam al-Syathiby memiliki peran yang sangat strategis untuk mewujudkan tujuan pendidikan. Tanpa seorang guru, maka sistem pendidikan akan pincang. Sosok guru tidak saja menjadi pengajar tapi juga pendidik bagi murid. Murid sebagai seseorang yang haus akan ilmu harus menyerap informasi dari guru secara sempurna atau komprehensif. Hal ini bertujuan agar murid tidak mengalami kerancuan dalam berfikir ketika informasi yang diserap tidak utuh. Maka seorang murid mesti menuntaskan seluruh halaqab ilmiyah dengan guru untuk mewujudkan kesempurnaan pemahaman.

Dalam pandangan Imam alSyathiby, tidak semua orang yang mengetahui tentang ilmu layak dijadikan guru. Sebab untuk menjadi guru ada nilai tanggungjawab, kemahiran, kepakaran dan lain sebagainya. Langgulung menjelaskan bahwa untuk menjadi sosok pendidik

TARBAWY: Indonesian Journal of Islamic Education - Vol. 5, No.1 (2018) 7 
atau guru iaharus menguasai ilmu yang diajarkan dan terampil mengajar dan pribadinya dapat diteladani. (Langgulung, 1988, hal. 85)

Oleh sebab itu, untuk menentukan seseorang pantas untuk dijadikan guru, Imam Syathiby menetapkan kriteria, yaitu:

Pertama, seorang guru mesti mengerjakan apa yang ia ajarkan agar terciptanya kesesuaian antara perbuatan dengan perkataan. Jika seandainya berbeda antara perkataan dan perbuatan maka ia bukanlah sosok yang pantas diambil ilmunya atau dijadikan panutan dalam menuntut ilmu. (al-Syathiby, 2006, vol. I, hal. 62). Pendapat ini sejalan dengan firman Allah Swt:

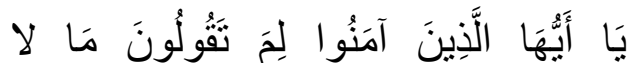

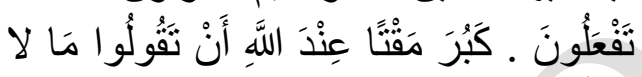
تَفْعَلُونَ تفعَنْ

"Wabai orang-orang yang beriman, kenapa kamu mengatakan sesuatu yang tidak kamu kerjakan?Amat besar kebencian di sisi Allah bahwa kamu mengatakan apa-apa yang tidak kamu kerjakan." (QS. As-Shaff: 2-3)

Ketika seorang guru mengamalkan apa yang ketahui, barulah itu menjadi milikinya. Jika ia sudah memilikinya barulah ia bisa berbagi dengan orang lain. Apabila ia tidak memiliki apa-apa, maka ia tidak akan bisa memberikan apa-apa. Pepatah Arab mengatakan,

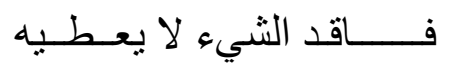

"Orang yang tidak memiliki sesuatu tidak. akan bisa memberikan sesuatu tersebut."

Maka seorang guru yang ideal, ia harus berbuat terlebih dahulu agar ada kesesuaian antara perkataan dan perbuatan. Kemudian barulah ia memberikan ilmunya kepada yang lain.

Kedua, keilmuan yang ia miliki mesti dilahirkan dari bimbingan seorang guru. Ketika menjadi murid, ia senantiasa mendampingi gurunya dalam berbagai mejelis ilmu dan kesempatan. Hal ini dicontohkan oleh perilaku sahabat yang senantiasa mendampingi Rasulullah Saw dalam berbagai situasi dan kondisi sehingga mereka menimba ilmu secara lansung dari sumbernya. (al-Syathiby, 2006, vol. I, hal. 62).

Senantiasa mendampingi guru dalam menuntut ilmu merupakan sebuah keharusan bagi seorang murid. Maka sebelum seseorang didaulat menjadi guru ia harus senantiasa menyertai gurunya sebagai penyambung mata rantai keilmuan.

Allah Swt memerintahkan kepada Musa As untuk menyertai Khidir As untuk menimba ilmu, dalam al-Qur'an Allah Swt berfirman:

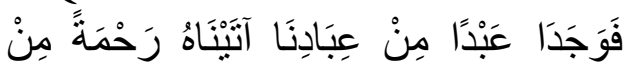

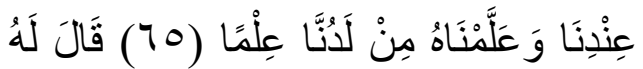

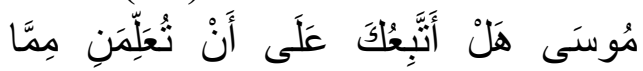

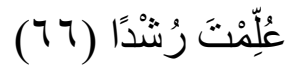

"Lalu mereka bertemu dengan seorang hamba di antara hamba-hamba Kami, yang telah Kami berikan rahmat [ilmu] kepadanya dari sisi Kami, dan yang telah Kami ajarkan ilmu kepadanya dari sisi Kami." * Musa berkata kepadanya, "Bolebkah aku mengikutimu agar engkau mengajarkan kepadaku ilmu yang benar yang telah diajarkan kepadamu (untuk menjadi) petunjuk?” (Qs. al-Kahfi: 65-66)

Dalam tafsir Jalalain dijelaskan bahwa (Musa berkata kepada Khidhir, "Bolehkah aku mengikutimu supaya

TARBAWY: Indonesian Journal of Islamic Education - Vol. 5, No.1 (2018) |8 
kamu mengajarkan kepadaku ilmu yang benar di antara ilmu-ilmu yang telah diajarkan kepadamu?)" yakni ilmu yang dapat membimbingku. Menurut suatu qiraat dibaca Rasyadan. Nabi Musa meminta hal tersebut kepada Khidhir. karena menambah ilmu adalah suatu hal yang dianjurkan. (Jalalain, 2003, vol. 15, hal. 301).

Jadi, benar bahwa seseorang yang akan dinobatkan menjadi guru, terlebih dahulu ia memepelajari ilmu dengan sungguh-sungguh. dengan di antaranya adalah senantiasa mendampingi gurunya agar ilmu yang disampaikan dapat mengalir dengan baik.

Ketiga, seseorang guru tersebut mesti meneladani guru-gurunya dan berakhlak sesuai dengan akhlak-gurugurunya. Para Tabi in menimba ilmu dari sahabat karena mereka senantiasa meneladani dan mengaplikasikan nilainilai yang mereka timba dari Rasulullah Saw. Dan begitulah yang berlaku dari generasi ke generasi. Jika hal ini tidak dilakukan maka akan memunculkan praktek bid'ah yang dapat merusak tradisi keilmuan. (alSyathiby, 2006, vol. I, hal. 63).

Berbicara tentang keteladanan berarti berbicara tentang kepribadian. Seorang guru mesti memiki kepribadian yang baik agar bisa ditiru atau dicontoh oleh murid-muridnya. Rasulullah Saw sebagai seorang guru yang ideal memiliki kepribadian yang luar biasa. Sehingga akhlak Rasulullah Saw diabadikan dalam al-Qur'an untuk ditiru. Allah Swt berfirman:

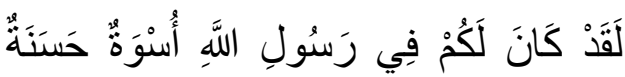

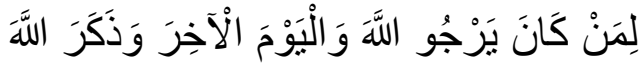

كَثِثرً

Sesunggubnya telab ada pada (diri) Rasulullab itu suri teladan yang baik bagimu (yaitu) bagi orang yang mengharap (rahmat) Allah dan (kedatangan) hari kiamat dan dia banyak menyebut Allah. (Qs. al-Ahzab: 21).

Kalian benar-benar mendapatkan teladan yang baik pada pribadi Nabi Muhammad. Teladan bagi orangorang yang mengharap kasih sayang Allah dan kesenangan hidup di akhirat. Teladan bagi orang-orang yang banyak berzikir mengingat Allah di setiap kesempatan, kala susah maupun senang. (Shihab, 2002, vol. XI, hal. 432).

Oleh sebab itu, seorang guru harus meneladani nilai moral dan karakter yang pernah ia saksikan dari guru-gurunya. Sebab seorang guru adalah sosok yang digugu atau diteladani maka mestinya, seorang yang dikukuhkan sebagai guru adalah orang yang meneladani dan mempraktekkan nilai-nilai akhlak yang dicotohkan oleh orang yang menjadi guru baginya.

Pilar ketiga, metode. Dalam proses pendidikan tidak cukup mengandalkan sebuah materi yang baik ataupun guru yang pintar. Akan tetapi, metode juga menjadi hal sangat menentukan dalam menentukan keberhasilan sebuah proses pendidikan.

Menurut Abuddin Nata, metode dapat berarti cara atau jalan yang harus dilalui untuk mencapai suatu tujuan. Selain itu, ada pula yang mengatakan bahwa metode adalah 
suatu saran untuk menemukan, menguji, dan menyusun data yang diperlukan bagi pengembangan disiplin ilmu tersebut. (Nata, 2005, hal. 143).

Jika metode yang digunakan baik maka hasilnya akan menjadi baik. Sebaliknya, jika metode yang digunakan salah maka hasilnya pun akan keliru. Oleh sebab itu, metode merupakan perkara yang sangat penting untuk diperhatikan oleh seorang pendidik agar ilmu yang disampaikan tertransfer dengan baik. Sehingga apa yang menjadi tujuan dalam pendidikan bisa terwujud dengan baik.

Imam al-Syathby menyebutkan:

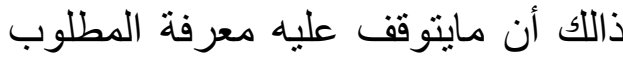

قديكون له طريق تقريبي يليق باجمهور وقد يكون له طريق لا يليق بالجمهور و

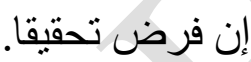

"Ketahuilab untuk mengajarkan sesuatu yang diinginkan terkadang ada metode pendekatan yang sesuai dengan sekelompok orang dan tidak sesuai dengan kelompok yang lainnya, dan jika dipaksakan maka tidak akan efektif.". (al-Syathiby, 2006, vol. I, hal. 38).

Dalam menyampaikan informasi ataupun ilmu, kita tidak mungkin menggunakan metode yang sama. Akan tetapi, kita harus memperhatikan orang yang akan menerima informasi tersebut sehingga kita bisa menentukan metode yang sesuai. Jika metode penyampaian yang digunakan sama, maka informasi tidak akan tersampaikan secara efektif dan tujuan yang dinginkan tidak akan tercapai.

Maka hal ini juga menjadi perhatian bagi Imam al-Syathiby dalam menjadikan metode penyampaian bagian dari pilar pendidikan. Dalam pandangan beliau, terkadang sebuah penyampain cocok dan efektif bagi sebagian orang dan mungkin saja tidak cocok atatu tidak efektif bagi sebagaian lain. Sehingga seorang guru mesti memperhatikan batas kemampuan yang dimiliki oleh muridnya dalam menerima ilmu. Jika dipaksakan untuk disamakan maka hasil yang dinginkan dari pendidikan tidak akan tercapai.

Menurut Armai Arif bahwa ada beberapa metode dalam al-Qur'an yang menjelaskan tentang menyampaikan ilmu dalam pendidikan, yaitu:

1. Pendidikan religius, bahwa manusia diciptakan memiliki potensi dasar fitrah atau bakat agama.

2. Pendekatan filosofis bahwa manusia adalah makhluk rasional atau berakal pikiran untuk mengembangkan diri dan kehidupannya.

3. Pendekatan rasio-kultural bahwa manusia adalah makhluk bermasyarakat dan berkebudayaan sehingga latar belakangnnya mempengaruhi proses pendidikan.

4. Pendekatan saintifik bahwa manusia memiliki kemampuan kognigtif dan afektif yang harus ditumbuh kembangkan. (Arief, 2002, hal. 41)

Hal hal yang juga perlu untuk diperhatkan dalam memilih metode dalam pendidikan yaitu: pertama, materi ilmu yang akan disampaikan. Kedua, penerima ilmu. Pada materi 
ilmu, pilihlah redaksi informasi atau materi ilmu yang mudah dipahami oleh orang yang menerima informasi. Jauhilah menggunakan istilah yang sukar dipahami. Sedangkan pada penerima ilmu, gunakanlah gaya pendekatan yang baik dan sesuai dengan tradisi mereka dengan memperhatikan kearifan lokal. Sehingga penyampaian menjadi lebih baik dan efektif. (al-Syathiby, 2006, vol. I, hal. 38).

Pilar keempat, Murid (peserta didik). Murid merupakan elemen yang sangat penting dalam pendidikan. Tidak bisa dibayangkan sebuah sistem pendidikan tanpa ada murid. Maka tidak ada gunanya ilmu, guru dan juga metode yang baik jika seandainya murid yang merupakan penerima ilmu tidak ada. Oleh sebab itu, kerbedaan murid juga harus sangat diperhatikan sehingga tujuan dari pendidikan tersebut dapat terwujud.

Menirut Toto peserta didik merupakan orang yang belum dewasa dan memiliki sejumlah potensi dasar (fitrah) yang perlu dikembangkan. (Toto, 2011, hal. 119). Dan Peserta didik adalah makhluk individu yang mempunyai kepribadian dengan ciriciri yang khas yang sesuai dengan pertumbuhan dan perkembangannya. Pertumbuhan dan perkembangan peserta didik dipengaruhi oleh lingkungan dimana ia berada. (Ramayulis, 2010, hal. 119).

Menjelaskan tentang murid, dalam al-Muwafaqat, Imam al-Syathiby menyebutkan:

وذللك أن الله عز وجل خلق الخلق غير عالمين بوجوه مصالحهم لا في الدنيا ولا لان

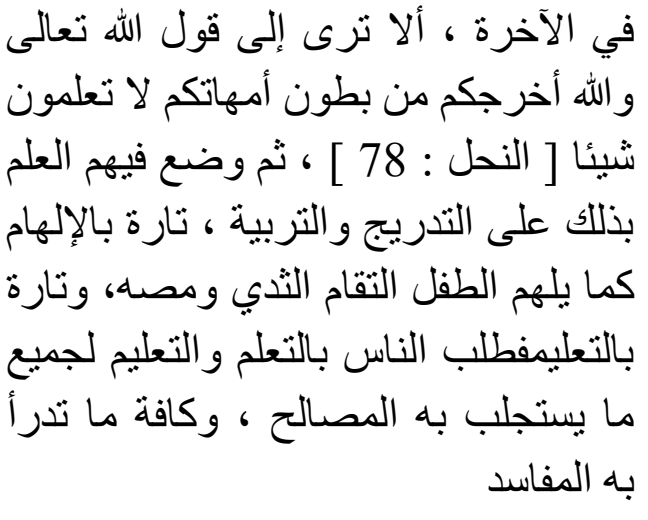

"Babwasanya Allab Swt menciptakan manusia tidak memiliki pengetabuan tentang kemashlabatan mereka di dunia dan akbirat. Allah Swt berfirman Allah-lah yang telah mengeluarkan kamu dari perut ibumu tanpa mengetahui sesuatu apapun (al-Nahal: 78). Kemudian anugrabkan kepada mereka ilmu dengan cara berangsur-angsur dan pendidikan. Maka terkadang dengan ilham, seperti seorang bayi yang lansung mennyusu kepada ibunya dan terkadang melalui pendidikan. Maka oleh sebab itu, manusia mesti menjadi murid dalam mempelajari segala sesuatu yang dapat mendatangkan kemashlabatan dan menjaubkan segala mudarat." (alSyathiby, 2006, vol. I, hal. 122).

Allah Swt menciptakan manusia dengan melahirkannya kepermukaan bumi tanpa mengetahui apapun, kecuali kebutuhan mendasar untuk menyusu kepada ibunya agar tetap bertahan hidup. Pengetahuan ini merupakan insting yang diwahyukan oleh Allah Swt kepada manusia dan bukan sesuatu yang dipelajari.

Sedangkan untuk menciptakan kemashlahatan dalam kehidupan selanjutnya, baik dunia dan akhirat maka manusia perlu ilmu. Dan untuk mendapatkan ilmu tersebut manusia harus belajar atau manusia harus mengenyam pendidikan. Oleh sebeb 
itu, merupakan sebuah kemestian bagi manusia untuk menjadi murid. Sebab segala sesuatu mesti dipelajari tidak didapatkan dengan begitu adanya.

Oleh sebab itu, murid juga merupakan pilar yang penting dalam pendidikan. Jika tidak ada murid maka proses pendidikan tidak akan berjalan. Kemashlahatan yang diinginkan juga tidak akan terwujud. Maka sebagai murid, seseorang harus mempelajari ilmu-ilmu yang berguna untuk mewujudkan kemashlahatannya di dunia dan kemashlahatannya di akhirat nantinya.

\section{PENUTUP}

Pendidikan merupakan satusatunya cara bagi manusia untuk bertahan dan mencipta peradaban dalam kehidupan. Tanpa pendidikan manusia tidak akan bisa menjelankan perannya sebagai khalifah dipermukaan bumi. Sebab, tidak seorangpun yang terlahir dalam keadaan tahu dengan segala-galanya.

Pendidikan merupakan sebuah sistem untuk sampai kepada tujuannya. Adapun tujuan pendidikan adalah untuk mendidik manusia agar mereka mampu mencipta amalan berkualitas agar terciptanya kehidupan yang penuh kebahagiaan di dunia dan di akhirat nantinya.

Layaknya sebuah sistem, ada pilar-pilar yang menjadi komponen agar sitem tersebut berjalan dengan baik dan seimbang. Sehingga tujuan pendidikan yang luhur dapat terwujud.

Imam al-Syathiby menjelaskan bahwa ada empat pilar penting dalam pendidikan, jika seandainya salah satu pilar tidak mendapatkan perhatian yang baik maka akan terjadilah ketidakseimbangan dalam sistem pendidikan.

Empat pilar tersebut adalah, ilmu yang merupakan materi dalam pendidikan. Ilmu yang dimaksud adalah ilmu yang berkaitan tentang syari'ah atau agama Islam. Hanya agama Islam yang mampu mendidik dan mendorong manusia kearah kehidupan yang lebih baik. Tiga alasan yang menjadikan Islam adalah materi ilmu yang utama, yaitu: perama Islam bersifat umum dan universal. Kedua, besifat tetap dan tidak akan lenyap. Ketiga, Islam rujukan dalam mencari solusi dalam kehidupan.

Pilar kedua adalah guru, sebab guru memiliki peran yang sangat penting untuk memindahkan pengetahuan yang ia miliki kepada murid. Kriteria guru menurut Imam al-Syathiby, Pertama, seorang guru mesti mengerjakan apa yang ia ajarkan agar terciptanya kesesuaian antara perbuatan dengan perkataan. Kedua, keilmuan yang ia miliki mesti dilahirkan dari bimbingan seorang guru. Ketiga, seseorang guru tersebut mesti meneladani guru-gurunya dan berakhlak sesuai dengan akhlak-gurugurunya.

Pilar ketiga adalah metode. Pada proses pendidikan tidak cukup mengandalkan sebuah materi yang baik ataupun guru yang pintar. Akan tetapi, metode juga menjadi hal sangat menentukan dalam menentukan keberhasilan sebuah proses pendidikan. Memilih metode yang baik adalah salah satu kunci keberhasilan dalam pendidikan. 
Pilar keempat adalah murid. Pada haikatnya semua manusia adalah murid. Manusia hanya diilhamkan untuk bertahan hidup ketika bayi. Sedangkan pada tahap kehidupan selanjutnya manusia mesti belajar dengan menjadi murid.

\section{REFERENSI}

Armai, A. (2002). Pengantar Ilmu dan Metodologi Pendidikan Islam. Jakarta: Ciputat Pers.

Cresswell, J. (1998). Research Design: Qualitative \& Quantitative Approaches. California: Sage Publications.

Feisal, J. A. (1995). Reorientasi Pendidikan Islam. Jakarta: Gema Insani Press.

Langgulung, H. (1985). Pendidikan dan Peradaban Islam. Jakarta: Pustaka Al-Husna.

Mahalli, J. (2003). Tafsir Jalalain. Lebanon: Maktabah Lubnan Nasyirun.
Nata, A. (2005). Filsafat Pendidikan Islam. Jakarta: Penerbit Gaya Media Pratama.

Ramayulis dan Syamsul Nizar. (2010) Filsafat Pendidikan Islam: Telaab Sistem Pendidikan dan Pemikiran Para Tokohnya. Jakarta: Kalam Mulia.

Shihab, M. Q. (2002). Tafsir AlMishbab: Pesan, Kesan dan Keserasian Al-Qur'an. Jakarta: Lentera Hati.

Suharto, T. (2011). Filsafat Pendidikan Islam. Yogyakarta: Ar-Ruz Media. Syathiby, A. I (2006). al-Muwâfaqât fi Ushûli al-Syari ah. Cairo: Daru al-Kutûb al-Ilmiyah.

Ubaidy, H. (1996). al-Syâthiby wa alMaqâshidu al-Syariah. Beirut: Dâru Qutaibah.

Undang-Undang Nomor 20 Tahun 2003 tentang Sistem Pendidikan Nasional. (2003). Jakarta: Depdikas. 